\title{
Introduction
}

\section{Toward a Thick Description of Chinese Philosophy}

In his Critique of Stammler, Max Weber (1864-1920) presented the following scenario:

Let us suppose that two men who otherwise engage in no "social relation"for example, two uncivilized men of different races, or a European who encounters a native in darkest Africa-meet and "exchange" two objects. We are inclined to think that a mere description of what can be observed during this exchange-muscular movements and, if some words were "spoken," the sounds which, so to say, constitute the "matter" or "material" of the behavior-would in no sense comprehend the "essence" of what happens. This is quite correct. The "essence" of what happens is constituted by the "meaning" which the two parties ascribe to their observable behavior, a "meaning" which "regulates" the course of their future conduct. Without this "meaning," we are inclined to say, an "exchange" is neither empirically possible nor conceptually imaginable. ${ }^{1}$

Weber's dated vocabulary (we no longer need to speak of "races" and of "darkest Africa") should not prevent us from recognizing the importance of his argument to both history and anthropology. A witnessthat is to say, an anthropologist or historian-who wishes to describe an "exchange" cannot be satisfied with relating the observable phenomena of the event, for this would be to ignore the underlying logic that Weber calls the "'essence' of what happens." From the point of the view of the agents themselves, the significance of the exchange lies not in their "muscular movements" but in the "meaning" that they attribute to the exchange and that, for the exchange to be completed, they must expect 
their colleagues to share. In short, the onus is to explain not the mere "muscular movements" but the "essence." This methodology is often called Weber's Verstehen thesis.

Verstehen in this sense is comparable to what Gilbert Ryle dubbed "thick description":

Two boys fairly swiftly contract the eyelids of their right eyes. In the first boy this is only an involuntary twitch; but the other is winking conspiratorially to an accomplice. At the lowest or the thinnest level of description the two contractions of the eyelids may be exactly alike. From a cinematograph-film of the two faces there might be no telling which contraction, if either, was a wink, or which, if either, was a mere twitch. Yet there remains an immense but unphotographable difference between a twitch and a wink. For to wink is to try to signal to someone in particular, without the cognisance of others, a definite message according to an already understood code. ${ }^{2}$

A twitch is not a wink, but the only way for an outsider to come to understand the difference between the two is to investigate the "understood code" that informs conspiratorial winking. It is not surprising that anthropologists have seized upon the concept of thick description for their own discipline. And the paradigm is equally useful in the study of cultural history, for the position of an ethnologist observing natives engaged in "exchange" is analogous to that of a historian trying to make sense of the scattered evidence found in historical sources. No less than in cultural anthropology, thick description in the domain of cultural history entails "sorting out the structures of signification... and determining their social ground and import." 3

In this book I present piecemeal attempts at the thick description of classical Chinese philosophy. This approach is only indirectly concerned with such considerations as the viability of Chinese philosophy today and its similarity or dissimilarity to Western philosophy, which animate most discussions of the subject within the framework of academic philosophy. The question of whether Chinese philosophy qualifies as genuine philosophy, seriously addressed by several scholars, ${ }^{4}$ depends entirely on the scope of one's definitions. If philosophy is made out to be an entity inseverable from the post-Platonic world, ${ }^{5}$ then classical Chinese philosophy is not and never can be "philosophy." But it certainly was something, and thick description is the best preliminary method to determine how Chinese thinkers conceived of their own enterprise. This book is not 
about whether Chinese philosophy is philosophy but about how Chinese philosophy is Chinese.

Who were the ancient Chinese philosophers? What was their intended audience? What were they arguing about? How did they respond to earlier thinkers and to each other? What rhetorical devices did they use to convey their ideas persuasively? Why did those in power wish to hear from them, and what did they claim to offer in retum for patronage? Such questions are essential to a broader understanding of the milieu in which Chinese thinkers flourished. Some scholars have begun to address the social aspects of these problems; ${ }^{6}$ but at the level of ideas, contemporary inquiries often submit descriptions that are too thin. Much ink has been spilled, for example, over the Procrustean question of whether Mohist ethics is deontological or consequentialist. ${ }^{7}$ The answer will matter only to a philosopher who is prepared to deracinate Mohism by disregarding what the ancient Chinese themselves thought was significant about Mohist philosophy. ${ }^{8}$ The purpose of the Mohists was not to work out a formal taxonomy of moral philosophy but to provide an alternative to Confucian ethics, which they regarded as objectionably partial in that it mandated obligations to other people in proportion to their proximity to oneself. The Mohists did not want to live in a world in which people treated their brothers with greater care than they did their neighbors. If such anachronistic terms as "deontological" and "consequentialist" must be imposed on Chinese thought, the only satisfactory assessment of Mohism is that it belongs to both categories: actions are right if and only if they produce material benefit, and actions that produce material benefit are right because Heaven mandates them. This would be a thicker understanding of what Mohism meant, both to its adherents and to its opponents.

Before proceeding to some concrete examples of what I mean by a thick description of Chinese philosophy-involving the significance of names and of paronomasia in Chinese philosophical literature-let me note that the necessary inquiries are difficult for technical reasons alone. Thus what is offered here is only a collection of illustrative studies, not a comprehensive disquisition. ${ }^{9}$ Chinese has never been considered an easy language (along with Arabic, Japanese, and Korean it is commonly reckoned as one of the hardest languages for an American to learn), ${ }^{10}$ and the archaic idiom in which classical Chinese philosophy has been transmitted is more demanding than the modern vernacular. Raising the cost of admission even further is the extraordinary series of archaeological 
discoveries in China since the 1970s. The artifacts that most directly affect the study of early Chinese thought are manuscripts, inscribed primarily on bamboo and silk, of which dozens have been found and which present unprecedented problems of interpretation. The basic work of deciphering the texts (and, in the case of bamboo texts, piecing the documents together strip by strip) is arduous, as they are written in a script that is older than the standard characters used in China today and that is not perfectly understood. Making sense of these materials requires an array of specialized skills (including epigraphy and linguistics, not the traditional strengths of Chinese studies in the United States), rendering progress slow under the best of circumstances and impossible without the ongoing cooperation of researchers across the globe. ${ }^{11}$

But if research has become more challenging, it has also become proportionally more rewarding. The changes in the field that have been brought about by the archaeological discovery of ancient manuscripts are profound. First, the many recent discoveries suggest that texts recorded on manuscripts circulated more widely in Warring States and Han China than was previously believed. When the documents from the tombs at Mawangdui 馬王堆 were first reported some thirty years ago, they produced a worldwide sensation, because nothing like them had ever been seen before. ${ }^{12}$ While Mawangdui must still rank as one of the greatest textual hoards in the archaeological record, we have today a much richer context in which to place these extraordinary finds. It is now apparent that feudal lords, and even well connected private citizens, could amass substantial and diverse libraries.

Moreover, the value of manuscripts is now more finely appreciated. Written texts were surely rare and valuable-they are rarer in tombs than bronzes, for example-but they were commodities that members of the elite commonly collected. This is a new insight. The older view of the nature and function of a text was influenced by the accounts of the transmission of the canons in such histories as the History of the Han (Hanshu 漢曹) ${ }^{13}$ According to that understanding, texts were sacred revelations; they were transmitted in secret from master to disciple and were safeguarded among doctrinal lineages. ${ }^{14}$ But the archaeological record does not square with that model. Excavated texts show influence from a multitude of intellectual sources, and, even more important, libraries are typically eclectic: that is to say, most collections of texts found in tombs include materials from several intellectual camps, many of which espoused beliefs incompatible with those of other represented schools.

A more likely thesis would hold that, by Warring States times, a na- 
tional literary culture had begun to emerge in China in which members of the highest classes participated by collecting a wide variety of texts. Ideology and region seem to have played a minor role in shaping the habits of bibliophiles. ${ }^{15}$ One finds commentaries on the Canon of Changes 易經 together with medical treatises at Mawangdui, demonological and hemerological almanacs together with legal handbooks at Shuihudi 睡虎地, and Confucian texts together with the Daode jing 道德經 (or Laozi 老子) at Guodian 郭店. Similarly, Confucian materials have been recovered not only from Qi 齊, where one might have expected them, but also from Chu 楚, which was never famous as a bastion of Confucianism. ${ }^{16}$ To this extent, the ancient Chinese intellectual world was more like our own than we, as cautious spectators of the "other," have recognized. The precise mechanisms by which manuscripts were copied and acquired are still unclear, but we may have to start thinking of Warring States China as a vast philosophical marketplace, with new and classic books readily available in all subjects and for all sufficiently affluent tastes.

A more specific example: The state of Qin 秦, widely disparaged as a semibarbaric frontier territory in earlier times, developed into a fearsome world leader in the late Warring States period. For centuries, the rise of Qin was normally explained as a consequence of its cruel administration: Lord Shang 商君 (d. 338 B.c.) was often credited with transforming Qin into a fighting machine by emphasizing agriculture and war and by reorganizing the populace into a system of subdivisions inspired by military command structure. ${ }^{17}$ Through its terrifying laws, Qin was supposedly able to make its people more productive and docile. But the details of these laws were never known.

Our understanding of the Qin dynasty was utterly transformed in 1975, when a substantial collection of statutes and legal manuals was discovered in a tomb at Shuihudi. ${ }^{18}$ Dating from the mid-third century B.c., these were the oldest legal texts ever discovered in China. The newfound Qin laws are difficult to read, because they use many unglossed technical terms and routinely allude to statutes whose content we can only guess at. Nevertheless, the laws are clear enough to explode the received image of the Qin state. Though they may appear harsh indeed to a modern reader, they were not extraordinarily severe for the times and were by no means arbitrary.

On the contrary, the laws from Shuihudi display a sophisticated awareness of such concepts as criminal intent, judicial procedure, defendants' rights, and the difference between what we would call common law and statutory law. Defendants were even allowed to appeal for a 
second inquest if they or their families disagreed with the results of the first. From our point of view, the most alienating aspects of the Qin laws are probably the mutilating punishments that they countenance, the instruments of collective responsibility, and the right of a father to demand the death of an "unfilial" son.

But even from our modern perspective, conditioned by our more liberal juridical traditions, it is impossible to deny the basic justice of the Qin laws. If a man or woman was to be punished, it could not be simply at the whim of an invidious magistrate. Every subject of the Qin state could expect to be treated according to unambiguous and predetermined protocols-and that is precisely the judicial environment that every viable law code must bring about. ${ }^{19}$ In sum, if these laws allow us any opportunity to speculate about the rapid ascendancy of Qin, then we must acknowledge that their outstanding feature is not their cruelty but their fairness. ${ }^{20}$

To be sure, some traditional scholars were able to arrive at similar conclusions on the basis of materials that had always been available, ${ }^{21}$ but statements about the Qin legal system had to remain tentative before the excavation of the tomb at Shuihudi. The continuing excavations in the People's Republic of China and the unimagined artifacts that they produce invite us to construct a thicker description of the early Chinese intellectual world than would have been feasible in previous generations.

What would a thick description of Chinese philosophy look like? It would begin by focusing on cultural phenomena that appear strange or surprising to us today. ${ }^{22}$ Consider Chinese names. Few accounts of classical Chinese thought have discussed or appreciated the fact that many early Chinese names reveal distinctive characteristics of the people they refer to. ${ }^{23}$ We do not normally think of "Descartes" or "Hobbes" as names that shed any particular light on Descartes or Hobbes as people. But Chinese names of this type are widespread. Two famous examples are the strikingly appropriate names Wen 文 (Cultured) and Wu 武 (Warlike), which refer to the founding kings of the Zhou 周 dynasty. ${ }^{24}$ The former is regularly praised for his moral and administrative accomplishments, the latter for his martial prowess and terrifying visage. Traditionally, Wen and Wu have been understood as posthumous names (shi 謚/諡), but recent evidence suggests that the kings may have acquired those names during their lifetimes. ${ }^{25}$ What is noteworthy, in either case, is that the names Wen and $\mathrm{Wu}$ seem to say something about the kings who bore them. Wen and $\mathrm{Wu}$ are hardly exceptional in this respect; they belong to a large 
class of early Chinese names that convey a definite meaning. Some further examples are presented below. ${ }^{26}$

The Mozi contains this story:

昔者宋文君鮑之時, 有臣曰祝觀鼓固嘗從事於庽, 祩子杖楫出, 與言曰：觀

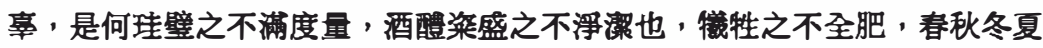
選失時，豈女為之與？意鮑為之與？觀鼓曰：鮑幼鸡，在荷繒之中，鮑何與

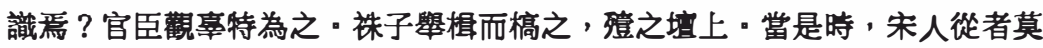
不見, 遠者莫不聞, 著在宋之春秋。諸侯傳而語之曰：諸不敬慎祭祀者, 鬼 神之誅, 至若此其櫭懒也・以若書之說觀之, 鬼神之有, 豈可疑哉。27

In the past, in the time of Bao, Lord Wen of Song [r. 610-589 B.c.], there was a functionary named Priest Guangu, who was following the service for a ghost. ${ }^{28}$ The medium ${ }^{29}$ emerged with a staff and said to him: "Guangu, why are the jade tablets and disks not up to their full measure? Why is the wine and millet unclean? Why are the sacrificial victims not unblemished and fat? Why are the offerings of spring, autumn, winter, and summer not timely? Did you do this, or did Bao do this?"

Guangu said: "Bao is young and immature; he is still in his diapers. What could Bao know about this? This was done expressly by the functionary in charge, Guangu."

The medium lifted his suff and beat him, killing him on top of the alm. At the time, those people in Song who were participating in the ceremony all saw it; those who were far away all heard of it. It is written in the annals of Song. The feudal lords transmitted [the story] and commented: "For whoever is not reverent and cautious about sacrifices, the punishment of the spirits is even as swift as this." Seeing that the story is in several books, one can hardly doubt that ghosts exist. ${ }^{30}$

The name Guangu 觀辜 means, literally, Faulty Observance. In a parallel account in a different text, the priest's name is given as Yegu 夜古, which does not have any obvious meaning. ${ }^{31}$ This evidence indicates that there was a popular ancient story in which a negligent priest was said to have been bludgeoned to death by a medium possessed by an irate spirit. In at least one version of the story, the name of the offending cleric was transmitted as Faulty Observance, which someone must have found fitting. Even if the story is not entirely fictitious, it is difficult to believe that the name Guangu was given at birth. We must take it as an epithet. ${ }^{32}$

There was a well-known jester in the fourth century B.c. named Chunyu Kun 淳于器. ${ }^{33}$ This figure is noteworthy because he is one of the 
most famous early examples of a zhuixu 䪷婿 (excrescent son-in-law), that is, a husband who is forced on account of indigence to reside with his wife's family. ${ }^{34} \mathrm{He}$ is usually referred to as Chunyu Kun, ${ }^{35}$ but Kun is best understood as an epithet: Shaved (like a slave) ${ }^{36}$ Like Guangu, Kun is probably not a name that was given at birth.

In Analects 13.18, we read:

葉公語孔子曰：吾黨有直躬者, 其父攘羊, 而子證之・ 子子曰：吾黨之直者 異柆是, 父為子喛, 子為父喛, 直在其中矣。97

The Lord of She said to Confucius: "In our village there is one Upright

Gong. His father stole a sheep, so the son testified against him."

Confucius said: "The upright people of my village are different from this. The fathers are willing to conceal their sons; the sons are willing to conceal their fathers. Uprightness lies therein."

Most commentators agree that $z h i$ (upright) is an appellation, but Gong is usually accepted as a genuine name. Gong means "self," however, and is not common as a personal name. Taking the entire phrase as an epithet-Self-Righteous-recasts the entire dynamic of this exchange. For then the Lord of She would be saying: "In our village there is one Self-Righteous..."-an implicit criticism in line with Confucius' response. As the passage is usually read, Confucius is understood to be rebuking the Lord of She for respecting a man who would testify against his father.

The origin of such a nickname is related in Springs and Autumns of Mr. Lü (Lüshi chunqiu 呂氏春秋):

襄子謁於代君而請䑦之, 先令舞者置兵其羽中數百人, 先具大金斗・代君

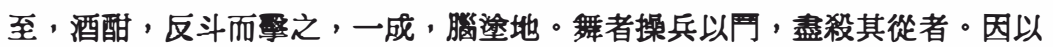
代君之車迎其妻, 其妻遥聞之狀, 磨算以自刺, 故趙氏至今有磨算之山與反 斗之號。35

Viscount Xiang [of Zhao, r. 474-425 в.c.], being visited by the Lord of Dai, proposed a banquet. He ordered several hundred dancers to place weapons in their plumed costumes and also prepared a large metal ladle. The Lord of Dai arrived, and when he was intoxicated with liquor, [Viscount Xiang] turned the ladle over and struck him; with one blow, his brains were spattered on the ground. The dancers grasped their weapons and attacked, killing all of his followers. Then [Viscount Xiang] used the chariot of the Lord of Dai to welcome the latter's wife [who was Viscount Xiang's sister], 
but when his wife heard the report from a distance, she sharpened a hairpin and stabbed herself with it. Thus to this day the House of Zhao has the mountain called Sharpened Hairpin ${ }^{39}$ and the appellation Overturned Ladle.

We are given to understand that Zhao finally annexed the territories of Dai. To my knowledge, Fandou 反斗 does not occur in any other context as a wry appellation of the Zhao clan. But the examples of SelfRighteous and Faulty Observance show that nicknames of this kind were not uncommon. One can imagine detractors referring to Overturned Ladle and his ill-gotten gains.

The supposed personal name of Sun Bin 孫㵒, the famous military strategist, is also an epithet.

孫䑚嘗與龐涓俱學兵法. 龐涓既事魏, 得為惠王將軍, 而自以為能不及孫

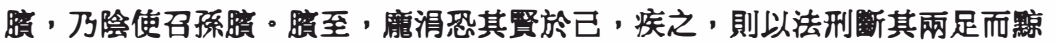
之, 欲鿵勿見。40

Sun Bin used to study military methods together with Pang Juan [d. ca. 341 B.c.]. When Pang Juan began to serve Wei, he became a general under King Hui [r. 370-335 B.c.] but did not consider his own abilities equal to those of Sun Bin. Thus he secretly summoned Sun Bin. When Bin arrived, Pang Juan was afraid that [Bin] was more talented, and, because he hated him, he used the penal laws to cut off [Bin's] two feet and have him tattooed, desiring thus to keep him hidden and unseen.

Since bin means "to amputate the feet," the name Sun Bin means precisely Sun Whose Legs Were Cut Off (or, perhaps more humorously, Kneecaps Sun). In a stimulating article, Jens Østergård Petersen contends further that the supposed sumame Sun should be taken as xun 遴, "to flee"; thus Sun Bin is The Legless One Who Fled. Following the earlier suggestion of Jaroslav Prǔšek, ${ }^{41}$ Petersen argues that the name of Sun Bin's famous ancestor Sun Wu 孫武 (Warlike), the putative author of the Sunzi, is also "as fictitious as [it] is meaningful." 42

Petersen presents several other instances of meaningful personal names in early China, which, for the sake of concision, are not rehearsed here. He has found, among other impeccable examples, a dissimulating poser named Deceptive and a presumptuous retainer named Reckless. ${ }^{43}$ One other obvious example that defies easy explanation is the personal name of Lord Wen of Jin 厽文公 (r. 635-627 B.c.): Chonger 重耳 (Double Ears), which apparently refers to some distinctive physical feature. 
Lord Wen is also noted for his "linked ribs" (pianxie 㥢勇), but it is not clear how the name Chonger could refer to his unusual ribs. ${ }^{44}$

These examples demonstrate that it was common in early China to refer to people by appellations that could not have been birth names but must be interpreted as meaningful epithets. Other examples could doubtless be added to the above. ${ }^{45}$ Recognizing this problem has consequences for an assessment of early Chinese texts. Once we see, for example, that the name of the negligent priest means Faulty Observance, we may be inclined to treat the entire story more like one of those lovely allegories in the Zhuangzi 莊子 (with such fabulous characters as Nag the Hump 哀駘 它 and Fancypants Scholar 士成綺 $)^{46}$-and less like history wie es eigentlich gewesen. The fact that these names can even appear in works pretending to be historical only underscores our obligation to be aware of them. Students of early China may wish to make a habit of asking themselves whether the personal names that they encounter in their research might be construed as meaningful epithets like Faulty Observance and Kneecaps Sun.

Ancient writers were aware of such names; indeed, they approved of them. There was a general sense that personal names, like all names, should reflect reality. For example, we read in the "Shifa" 湓法 (a manual on selecting appropriate posthumous names): ${ }^{47}$

湓者行之跡也・躆者功之表也・車服者位之章也・是以大行受大名, 細行受 細名。行出於已，名生於人。48

Posthumous names are traces of conduct. Appellations are indications of accomplishment. Chariot and dress are displays of status. Therefore great conduct receives a great name; trifling conduct receives a trifling name. Conduct emerges from the self; the name is born of others.

The beginning of this passage is not surprising; most historians of early China would readily agree that posthumous names were chosen to encapsulate a judgment about the deceased's conduct in life. However, the text says more than that: it is not only posthumous names that should be appropriate; every name should "indicate" or "display" the accomplishments and status of the person in question. In technical terms, the passage is saying that a person's several names-the shi, the hao (appellation), and the ming (personal name), which, in later times at least, are kept strictly distinct ${ }^{49}$-are all essentially of the same kind. Choosing the 
right appellation for someone was conceived as simply another species of "rectifying names" (zhengming 正名), a primary concern of early Chinese philosophy. ${ }^{50}$ Naming was an essentially philosophical act.

Another name whose significance has often been misunderstood is $\mathrm{Xi}$ Wangmu 西王母, which denotes the goddess of immortality. The stock translation of Xi Wangmu is Queen Mother of the West, but this reflects a misprision. "Queen mother" in everyday English refers to the mother of a ruler, but it is not suggested in any of the traditions concerning $\mathbf{X i}$ Wangmu that she earned her title by virtue of being the mother of a king. ${ }^{51}$ The translation "Queen Mother" may be intended as something similar to "royal mother"-but if this is what translators have in mind, they should say "Royal Mother" rather than "Queen Mother."

However, "Royal Mother" would still be imprecise, because wang in this context probably does not carry its basic meaning of "king, ruler." Wangmu is a cultic term referring specifically to a deceased paternal grandmother. This usage is explained in the classical glossary called Erya 爾雅:

父為考, 母為妣・父之考為王父, 父之妣為王母・王父之考曾祖王父, 王父 之母為曾祖王母.52

One's father is one's kao [i.e., "deceased father"]; one's mother is one's $b i$ [i.e., "deceased mother"]. One's father's kao is one's wang-father; one's father's $b i$ is one's wang-mother. One's wang-father's kao is one's ancestral wang-father; one's wang-father's $b i$ is one's ancestral wang-mother.

The precise meaning of wang in this passage is not obvious. The commentator Guo Pu 郭榉 (A.D. 276-324) suggests, plausibly, that "one adds wang in order to honor them” 加王者尊之. The opinion of Hao Yixing 郝 憼行 (1757-1825) is similar: "Wang means 'great,' 'lordly'; it is an appellation honoring one's superiors. Thus wang-father and wang-mother are also called 'great father' and 'great mother'”王, 大也, 君也, 尊上之 稱・故王父母亦日大父母也. ${ }^{53}$

Although this nomenclature is rare in received texts, ${ }^{54}$ excavated manuscripts reveal that it was standard in ancient formulaic language. In the almanacs 日害 from Shuihudi, various diseases are said to be cured by offerings to wangfu or wangmu, as in the following example: 
丙丁有疾, 王父為崇・得之赤肉、雄雞、酒。庚辛病, 壬有閒, 癸作。若不 作, 煩居南方, 㓟在南方, 赤色死・戊已有疾, 巫堪行, 王母為崇・得之於 黄色索魚、堇酒・壬癸病, 甲有閒, 乙作。若不作, 煩居邦中, 㓺在西方, 黃色死。55

If there is an illness on bing and ding days, it is a calamity caused by wangfu. One gets it ${ }^{56}$ from red meat, roosters, and liquor. On geng and xin days, [the subject will still be] sick; on ren day he will begin to be cured; on gui day there will be activity [i.e., the subject will anise from bed]. If there is no activity, then those who dwell in the south will have headaches; those who are in the south will be injured; and those associated with the color red will die.

If there is an illness on $u n e$ and $\ddot{j}$ days, Shaman Kan carries it out [?] ${ }^{57}$ it is a calamity caused by wangmu. One gets it from yellow dried fish and tawny liquor. On ren and gui days, [the subject will still be] sick; on jia day he will begin to be cured; on yi day there will be activity. If there is no activity, then those who dwell in the center of the state will have headaches; those who are in the west will be injured; and those associated with the color yellow will die.

It is crucial to keep in mind that wangfu and wangmu refer to one's grandfather and grandmother after they are deceased and not while they are still alive-in other words, only when they have entered the spirit world. This is significant, because in other contexts, wang is used more generally to denote spirits of any kind. A good example appears in an offhand comment by the philosopher Xunzi 荀子 (third century B.C.):

\section{郊者, 并百王於上天而祭祀之。58}

In the suburban sacrifice, one unites the many wang with Heaven Above and sacrifices to them.

The commentary of Yang Liang (A.D. 818) notes, reasonably, that baiwang should be understood as baishen 百神, “the many spirits." 59 Indeed, there is a similar passage in the Ritual Records (Liji 禮記) that reads baishen instead of baiwang. ${ }^{60}$ The use of the term wang to denote a spirit may not be common, but it should not be considered exceptional either, because lofty terrestrial titles-such as jun 君, “lord"; gong 公 “lord, duke"-frequently appear in the names of spirits and deities, including those that are construed as female. ${ }^{61}$

There seems to be abundant textual support, then, for taking the 
wang in Xi Wangmu in the sense of "spirit, divinity." After all, she is a goddess, not a queen. If we apply the terminology of Erya and the Shuihudi almanacs, then Xi Wangmu means precisely "Deceased $\mathrm{Pa}$ ternal Grandmother of the West." But since the implication of her title is evidently that she is a powerful spirit-like a deceased paternal grandmother-a more general rendering, such as "Spirit Mother of the West," may best capture the sense of Xi Wangmu. ${ }^{62}$

Why is wang used in this sense of "powerful spirit"? There are several defensible explanations. One was offered by Guo Pu and Hao Yixing: wang is simply an honorific epithet. But there are other possibilities. In this sense, wang might be understood as wang 往, "to depart": thus wangmu 王/往母, "departed mother"; ${ }^{63}$ after all, wang 王 is used in place of wang 往 in the Odes. ${ }^{64}$ Moreover, Edward H. Schafer demonstrated in a brilliant article that wang 王 belongs to a series of words with strong connotations of shamanism, including kuang 狂, "maniacal, possessed"; wang 尪, "(crippled) shaman"; and kuang 匡, "male shaman." Schafer concludes: "this group of words suggests strongly the shamanistic character of the prehistoric Chinese king, and probably also the delirium of the great shaman when possessed by a spirit." 65

Finally, wàng 王 can function as a verb of obscure meaning that is occasionally used as the predicate of a subject shen 神: spirits naturally wang. The most familiar example appears in the Zhuangzi:

澤雉十步一啄, 百步一飲, 不靽畜乎焚中・神踓王, 不善也。66

The swamp pheasant must take ten steps for one peck and a hundred steps for one drink, but it does not ask to be kept in a cage. Although its spirit will wang, it will not be in its element.

In other words, even though the "spirit" of a caged pheasant will be well nourished, the bird is more content wandering along the marshes-a more difficult life, but a freer one. (Zhuangzi's diction implies subtly that a caged pheasant is dead, like an ancestral spirit that one feeds with sacrifices.) This wang is usually glossed as the equivalent of wang 旺/㫿, “to flourish, to gleam." ${ }^{\prime 7}$ Thus if wang was understood in the ancient language as an attribute of satiated spirits, wangmu 王/旺/㫿母 may mean something like "wanging mother, numinous mother." ${ }^{68}$ This is surely closer to what devotees understood by the name than the conceptually thin title, "Queen Mother of the West," that sinologists have conferred on the goddess. 
The interrelations among all these words pronounced wang may remind one of another pervasive feature of Chinese philosophical literature, namely, its use of "paronomastic glosses," by which certain essential terms are explained by homophones (or near homophones) with more accessible meanings. ${ }^{69}$ The most frequently cited example is the phrase Ren zhe, ren ye 仁者, 人也, which appears in the Application of Equilibrium 中庸, one of the central texts in the classical tradition. ${ }^{70}$ The first ren (humanity) denotes the virtue that Confucius singled out as the most important goal of self-cultivation. ${ }^{71}$ Understandably, people wanted to know precisely what ren meant, and Confucius was generally unwilling to explain it simply. The Confucian Analects are replete with episodes wherein one or more of the Master's disciples ask whether such-and-such an action or attitude qualifies as ren; Confucius' answers are typically vague, and he is careful never to give a neat definition. ${ }^{72}$ (In practical terms, Confucius' ren means something close to acting with respect to another as one would want another to act with respect to oneself if one were in that other person's situation.) ${ }^{73}$

The second ren means "person," "human being."74 These characters are not simply homophones today; rather, they probably represent two different ways of writing the same word. (The reconstructed Old Chinese pronunciation for both characters is *nin. $)^{75}$ Ren 仁 came to be the special character used in those instances where the "state of being human"-or the virtue of "humanity"-was intended. So the Application of Equilibrium defines the term as follows: "'Humanity' is 'human." This paronomastic gloss is more informative than it may seem: it tells us that the virtue of ren originates among people and that its very etymology is bound up in the word for "human being."76 In giving its own pithy definition of ren, the Application of Equilibrium appeals to the reader's eagerness to be provided with a simple and memorable explanation of a concept that frustrated Confucius' own disciples.

Such paronomastic glosses, however, cannot always be taken to be etymological in nature. For example, the scholastic text known as Comprehensive Discussions in the White Tiger Hall (Baihu tong 白虎通) uses paronomasia to explain why there are nine conventional groups of kinfolk:

尚書曰: 以親九族・族所以有九何? 九之為言究也・親疏恩愛究竟, 謂之九 族也。77

It is said in the Exalted Documents: "Thus he was intimate with the nine branches of his kin." 78 Why is it that there are nine branches of kin? "Nine" 
( $\left.{ }^{*}{ }^{w} u\right)$ is as if to say "end" (*kuw:). ${ }^{79}$ The kindness among relatives persists to the end, so one refers to the nine branches of kin. ${ }^{80}$

Such casuistry has earned the Comprehensive Discussions a dubious reputation among modern readers, but this posited connection between "nine" 九 and "end" 究 rests on one of the basic convictions of Chinese philosophy. Language corresponds to reality; words that belong together consequently ought to denote concepts that belong together. Though "nine" and "end" are not obviously cognate, they happen to be nearly homophonous in Old (as in Modern) Chinese and are represented by two characters that share the same graph: 九. How is a translator supposed to convey all this? The case of "humanity" presents less of a problem, because there we can safely use two words with the same English root (e.g., "humanity" and "human") to capture the intended etymological thrust. But to capture all the dimensions of this gloss, the translator would have to find two unrelated words for "nine" and "end" that not only sound similar but actually appear similar when written out. The force of this statement transcends language, because it derives from the very shape of the written characters. One can appreciate how the translator of ancient Chinese philosophy attempts to translate not merely a different language, but an aesthetic sensibility that must be completely alien to readers of languages written in an alphabetic script. ${ }^{81}$

Other instances of paronomasia in ancient Chinese philosophical writing fall into yet a third category. Consider the following example from the Mencius:

孟子曰：君子之於物也，爱之而弗仁。於民也，仁之而弗親・親親而仁民， 仁民而爱物。82

Mencius said: The noble man is kind to animals, but does not treat them with humanity. He treats people with humanity, but he is not intimate with them. He is intimate with his parents and treats people with humanity; he treats people with humanity and is kind to animals.

In other words, the noble man treats different kinds of creatures according to a scale of moral obligations, ranging from "being kind" to animals to "being intimate" with his own parents. The crux of the statement comes in the phrase qinqin, translated above as "being intimate with one's parents." The basic sense of qin is "close"; the specialized sense of "parent" (or "agnatic relative") is derived from the fact that one's parents are 
the people who are closest to oneself. So qinqin incorporates a variety of meanings: "being close to those whom one ought to be close to"; "treating one's parents as one ought to treat one's parents"; and so forth. Classical readers would have recognized these several meanings instantly, as have most commentators through the centuries.

What is no longer obvious-and what translators rarely convey-is that the words ren (humanity) and qin (intimate) are cognate in Old Chinese. The reconstructed Old Chinese pronunciations are ${ }^{*}$ nin and ${ }^{*}$ snin, ${ }^{83}$ respectively. This point is essential to understanding the rhetorical aspect of Mencius' statement: he is saying that we should treat people with ren, or "humanity," for this is what they deserve-but we should treat the people who are closest to us in a way that is related to ren but reserved for our parents and intimate relations. The link between ren and qin would have made this seem like a perfectly natural claim to an ancient Chinese audience. This is an example of a third type of paronomasia: words that sound similar but are written with characters whose forms do not reveal these connections. Such cases can be more problematic for the translator still, because centuries of sound change have frequently obscured the paronomasia.

Mencius plays on this family of words on a number of occasions. ${ }^{84}$ Elsewhere, he declares:

\section{不信仁賢，則國空虛。85}

If [the lord] does not trust men of humanity and talent, the state will become empty and void.

The word for humanity here is the same ren discussed above. The new term is $x$ in 信, or "trust." The graphic composition of this character is telling: the grapheme on the left is a form of ren 人, "human," and is borrowed for its phonetic value. For it turns out that xin, too, is cognate with ren $人$ and ren 仁. The Old Chinese reconstruction of xin is *snins, which represents the same root $*_{\text {nin }}$ with a prefix and the prolific Old Chinese suffix *-s. The etymology of the word xin is not lost on Mencius. He juxtaposes the two words so as to highlight why it is natural that "men of humanity" should be "trusted": the word for "trust" is simply a derivative of the word for "humanity."

Mencius then proceeds further in this vein by bringing in xian 賢, or "men of talent." The Old Chinese pronunciation of xian is *gin, and the reigning assonance among ren, xin, and xian is no coincidence: ${ }^{*}$ nin, 
*snins, *gīn. Xian is not cognate with ren and xin, but the manif est similarity in sound sufficed for Mencius' purposes. We are to infer that we should implicitly "trust" men of "humanity," because xin and ren share the same root and also that we should "trust" men of "talent," because xian belongs to the same rhyme group. These ideas are conveyed in Old Chinese entirely by suggestion and association. Mencius is tapping into fundamental linguistic connections that would have been second nature to a speaker of Mencius' language.

Ancient Chinese writers themselves were aware that the words with which they expressed their ideas could be skillfully chosen to resonate with correspondences ingrained in the audience's mind. Xunzi once remarked:

\section{名有固善，徑易而不拂，謂之善名。86}

Names have intrinsic goodness. If they are direct, easy, and not contrary [to their meaning], they are called good names.

Scholars are often perplexed by this statement, since it comes at the end of a long and insightful discussion that anticipates Saussure in demonstrating the intrinsic arbitrariness of names. How could Xunzi suddenly shift his ground and argue that good names bear some elemental relation to their meanings? It seems that Xunzi went even beyond Saussure and recognized a linguistic phenomenon similar to the "nonarbitrariness theory of language" of Roman Jakobson: the names of objects are indeed absolutely arbitrary, but from the point of view of speakers, certain names may still seem especially appropriate. (To use Jakobson's example: when a German-speaking woman was told that the word for "cheese" in French is fromage, she replied, "Käse' ist doch viel natürlicher! ${ }^{\prime \prime}{ }^{87}$ Thus Xunzi well understood the power of Mencius' arguments, which built on the ancient Chinese reader's sense that such words as "humanity" and "trust" belong together. ${ }^{88} *$ Nin and *snins sound right.

Translators cannot hope to preserve this dimension of Mencius' writing, precisely because the essential linguistic connections would not exist in any other language. Similarly, it is impossible to "translate" the gloss on "nine" and "end," because the connection between the two concepts exists only in the context of the Chinese writing system. So the best that we can do in such instances is to translate the text as faithfully as possible and then explain the dimensions of the original in the form of annotation. But the annotation is crucial. ${ }^{89}$ If we fail to highlight these 
problems, we fail to convey to a foreign reader the world of concerns of the original text in its culture. The result would be the transmogrification -not translation-of a complex Chinese statement into specious and facile English.

"Translation" must entail more than that. As Quine demonstrated long ago, ${ }^{90}$ the problem of translation is at root an ontological problem: it is not merely the routine transposition of a set of words in one language into another set in another language but the attempt to recreate a speaker's entire world view in an idiom that fits an observer's entirely separate world view. We must translate worlds, not words. 